\title{
Penentuan Kondisi Optimasi Transpor Ion Cu (Ii) Melalui Teknik Membran Cair Fasa Ruah Secara Simultan Dengan Oksin Sebagai Pembawa
}

\author{
Refinel, Admin Alif, Rizki Octarini \\ Laboratorium Elektrokimia, Jurusan Kimia, FMIPA Universitas Andalas
}

\begin{abstract}
Determination of optimum condition and kinetic analysis $\mathrm{Cu}$ (II) iontransport by simultaneous bulk liquid membrane has been studied. Optimum condition for resource phase with $\mathrm{Cu}$ (II) ion concentration as $3,147 \times 10^{-4} \mathrm{M}$ obtained at $\mathrm{pH} 3$ receiving phase with $\mathrm{H}_{2} \mathrm{SO}_{4}$ concentration $0,15 \mathrm{M}$ and transport time as long as 3 hours through chloroform membrane using oxine $17,5 \times 10^{-4} \mathrm{M}$ as carrier. Transportation rate of $\mathrm{Cu}$ (II) ion decided by comparasion changer-over rest concentration in resource phase $\mathrm{Rs}$ and transpoted to receiving phase $\mathrm{Rp}$ and then monitored by Atomic Adsorbtion Spectrophotometre (AAS). Kinetic of transport $\mathrm{Cu}$ (II) ion process by simultaneous bulk liquid membrane technique fulfil irreversible consecutive first order reaction with transport $\mathrm{Cu}$ (II) ion gave $\left(k_{1}\right)$ value as 0,0442 minute $^{-1}$ and $\left(k_{1}\right) 0,0372$ minute $^{-1}$. Simultaneous bulk liquid membrane method can be the alternative method in the determination of optimum condition and kinetic analysis of metal ions transport.
\end{abstract}

Key words: $\mathrm{Cu}$ (II) ion, kinetic, optimum, transport, liquid membrane, simultaneous

\section{PENDAHULUAN}

Penggunaan membran cair merupakan suatu alternatif dari eksraksi pelarut untuk pemisahan ion-ion logam. Membran ini mampu untuk memberikan seluruh fasilitias antarmukanya untuk tempat terjadinya proses`transpor pada sistem pemisahan ${ }^{[1]}$. Bermacam senyawa pembawa (carrier) yang ditambahkan ke dalam membran cair sebagai mediator untuk memacu proses transpor ion logam tersebut dalam pemisahan telah banyak diuji keakuratannya.Disini transport terjadi berdasarkan perbedaan difusi, karena adanya perbedaan kelarutan komplek ( ion- carrier) pada antarmuka, kompleknya reversible antara senyawa pembawa dengan ion logam yang akan ditranspor ${ }^{[2]}$.

Percobaan penentuan optimasi transport ion logam dari fasa sumber ke fasa penerima secara simultan ( serentak ) pada metoda membran cair fasa ruah dilakukan dengan menggunakan sel membran yang terdiri dari sel fasa sumber dan beberapa sel fasa penerima dengan variasi $\mathrm{pH}$ tertentu atau sebaliknya. Keuntungan percobaan secara simultan ini adalah percobaan penentuan optimasi transport ion logam dari fasa sumber ke fasa penerima dilakukan dalam satu langkah percobaan pada kondisi yang sama sehingga faktor kesalahan menjadi lebih kecil.

\section{Kecepatan Proses Transpor Ion Cd(II) melalui Teknik Membran Cair Fasa Ruah.}

Secara teoritis perubahan perbandingan konsentrasi ion $\mathrm{Cd}(\mathrm{II})$ dalam fasa sumber (Rs), fasa membran $(\mathrm{Rm})$, dan fasa penerima ( $\mathrm{Rp})$ memenuhi persamaan :

$$
\begin{aligned}
& \mathrm{Rs}+\mathrm{Rm}+\mathrm{Rp}=1 \\
& R s=\frac{C s}{C s_{o}} \quad R m=\frac{C m}{C s_{o}} \quad R p=\frac{C p}{C s_{o}}
\end{aligned}
$$

dengan : $\mathrm{Cs}=$ konsentrasi ion $\mathrm{Cd}(\mathrm{II})$ sisa dalam fasa sumber, $\mathrm{Cs}_{\mathrm{o}}=$ konsentrasi ion $\mathrm{Cd}$ (II) awal dalam fasa sumber saat $\mathrm{t}=0, \mathrm{Cm}$ = konsentrasi ion $\mathrm{Cd}(\mathrm{II})$ dalam fasa membran, dan $\mathrm{Cp}=$ konsentrasi ion $\mathrm{Cd}(\mathrm{II})$ yang tertranspor ke dalam fasa penerima.

Pada dasarnya, perubahan konsentrasi ion $\mathrm{Cd}(\mathrm{II})$ dalam fasa sumber (Rs) menurun secara eksponensial terhadap waktu transpor. 
Selanjutnya untuk perubahan konsentrasi ion $\mathrm{Cd}(\mathrm{II})$ dalam fasa penerima (Rp) meningkat secara sigmoid sedangkan $\mathrm{Rm}$ berada dalam suatu keadaan maksimum pada titik tertentu. Hasil ini cenderung menunjukkan bahwa transpor ion $\mathrm{Cd}(\mathrm{II})$ mengikuti hukum kinetik reaksi konsekutif irreversibel orde satu berdasarkan skema kinetik.

$$
\underset{\mathrm{s}}{\mathrm{Cd}^{2+}} \underset{2(\mathrm{H}-\mathrm{ox})}{\stackrel{\mathrm{k}_{1}}{\rightarrow}} \underset{\mathrm{m}}{\mathrm{Cd}(\mathrm{ox})_{2}} \underset{\mathrm{EDTA}}{\stackrel{\mathrm{k}_{2}}{\rightarrow}} \mathrm{Cd}(\mathrm{EDTA})+2 \mathrm{Ox}^{-}
$$

dengan $\mathrm{s}$, $\mathrm{m}$, dan $\mathrm{p}$ adalah ion $\mathrm{Cd}(\mathrm{II})$ dalam fasa sumber, fasa membran, dan fasa penerima. Skema kinetik dapat dijelaskan dengan persamaan :

$$
\begin{aligned}
& \frac{d R_{s}}{d t}=-\mathrm{k}_{1} \mathrm{Rs}=\mathrm{Js} \\
& \frac{d R_{p}}{d t}=\mathrm{k}_{2} \mathrm{Rm}=\mathrm{Jp} \\
& \frac{d R_{m}}{d t}=\mathrm{k}_{1} \mathrm{Rs}-\mathrm{k}_{2} \mathrm{Rm}
\end{aligned}
$$

dengan $\mathbf{J}$ adalah kecepatan pengaliran (fluks) dan $\mathrm{k}_{1}$ dan $\mathrm{k}_{2}$ adalah konstanta kecepatan orde satu yang masuk ke dalam membran dan keluar dari membran. Bila $\mathrm{k}_{1} \neq \mathrm{k}_{2}$, hasil integrasi persamaan di atas adalah :

$$
\begin{aligned}
& \mathrm{Rs}= \exp \left(-\mathrm{k}_{1} \cdot \mathrm{t}\right) \\
& \mathrm{Rp}= 1-\frac{1}{k_{2}-k_{1}}\left[\mathrm{k}_{2} \exp \left(-\mathrm{k}_{1} \cdot \mathrm{t}\right)-\mathrm{k}_{1}\right. \\
&\left.\exp \left(-\mathrm{k}_{2} \cdot \mathrm{t}\right)\right] \frac{k_{1}}{k_{2}-k_{1}}\left[\exp \left(-\mathrm{k}_{1} \cdot \mathrm{t}\right)-\right. \\
&\left.\left.\mathrm{k}_{2} \cdot \mathrm{t}\right)\right]
\end{aligned}
$$

Dapat dilihat bahwa Rs vs t menghasilkan kurva penurunan eksponensial dimana variasi waktu antara $\mathrm{Rm}$ dan $\mathrm{Rp}$ adalah bieksponensial dan bukan merupakan kurva linear ${ }^{3}$.

\section{METODOLOGI}

\section{Bahan kimia digunakan}

Bahan yang digunakan mempunyai tingkat kemurnian yang tinggi yaitu : $\mathrm{CuCl}_{2} \cdot \mathrm{H}_{2} \mathrm{O}$, $\mathrm{H}_{2} \mathrm{SO}_{4}$, kloroform, oksin. Bahan kimia yang lainnya adalah ammonium hidroksida, asam asetat, asam klorida,asam nitrat, buffer asetat, buffer ammonium klorida dan akuades.

\section{Alat-alat yang digunakan}

pH meter (Hanna Instrumenta), Spektrofotometer Serapan Atom (Model ALFA-4 London Inggris), Sanwa digital tachometer (Model/SE-100) untuk mengukur kecepatan pengadukan, sel membran cair fasa ruah, stop wach. Magnetic stirrer, neraca

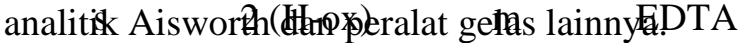

\section{Metode}

Ke dalam beker gelas $500 \mathrm{~mL}$ ( diameter dalam 8,85 Cm ) dimasukan $150 \mathrm{~mL}$ kloroform yang mengandung oksin $17,5 \times 10^{-4} \mathrm{M}$ dan dicelupkan 7 tabung kaca selindris dengan diameter dalam yang sama $(2,05 \mathrm{Cm})$ dan simetri yang memisahkan dua fasa larutan yaitu fasa sumber dan fasa penerima seperti Gambar $1^{[4]}$.

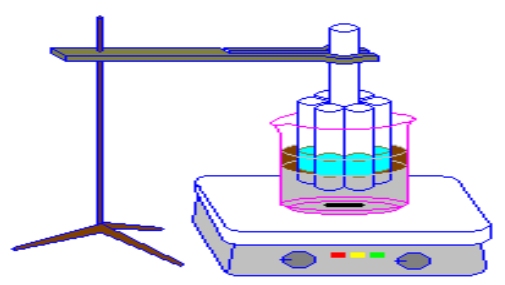

Gambar 1. Model reaktor transpor ion logam melalui membran cair fasa ruah secara simultan

Proses transport dapat dilakukan dengan dua metode berbeda. Metode pertama digunakan untuk variasi $\mathrm{pH}$ fasa sumber dan waktu traspor yaitu dimasukan $5 \mathrm{~mL}$ ion $\mathrm{Cu}$ (II) 17,5 x $10^{-4} \mathrm{M}$ sebagai fasa sumber pada ke 6 tabung silinder dengan $\mathrm{pH}$ yang bervariasi dan fasa penerima berisi $35 \mathrm{~mL} \quad \mathrm{H}_{2} \mathrm{SO}_{4} 0,15 \mathrm{M}$ di sekeliling tabung silinder di atas fasa membran.

Metode ke dua yang dapat digunakan untuk penentuan variasi konsentrasi $\mathrm{H}_{2} \mathrm{SO}_{4}$ fasa penerima dan waktu transport yaitu dimasukan $35 \mathrm{~mL}$ fasa sumber ion $\mathrm{Cu}(\mathrm{II})$ pada $\mathrm{pH}$ optimum disekeliling 7 tabung silinder di atas fasa membran dan fasa penerima berisi $5 \mathrm{~mL}$ 
$\mathrm{H}_{2} \mathrm{SO}_{4}$ dalam ke 6 tabung silinder dengan konsentrasi bervariasi.

Teknik operasi dilakukan melalui pengadukan dengan memakai magnetic stirrer pada kecepatan $340 \mathrm{rpm}$ selama beberapa waktu tertentu. Setelah didiamkan selama 15 menit, fasa sumber dan fasa penerima diukur konsentrasi ion $\mathrm{Cu}$ (II) yang terkandung didalamnya dengan spektrofotometer serapan atom (SSA).

\section{HASIL DAN DISKUSI}

\section{Penentuan pH Optimum Fasa Sumber}

Penentuan $\mathrm{pH}$ optimum fasa sumber dalam proses transport ion $\mathrm{Cu}(\mathrm{II})$ diperlajari dengan tujuan untuk melihat pengaruh variasi $\mathrm{pH}$ fasa sumber terhadap transport ion $\mathrm{Cu}$ (II) ke fasa membran dalam waktu yang bersamaan.
Pada Gambar 2 terlihat bahwa $\mathrm{pH}$ optimum transport ion $\mathrm{Cu}$ (II) adalah pada $\mathrm{pH} 3$ yang di tandai paling kecilnya jumlah ion $\mathrm{Cu}(\mathrm{II})$ yang tersisa di fasa sumber. Berdasarkan literatur diketahui bahwa ion $\mathrm{Cu}$ (II) dapat terekstraksi dengan oksin dalam kloroform pada rentang pH 2,8-12 yang menghasilkan kompleks $\mathrm{Cu}-$ oksinat yang berwarna kuning ${ }^{[5]}$. Pada $\mathrm{pH}$ kecil dari 3 jumlah ion $\mathrm{H}^{+}$semakin banyak di fasa sumber akan mengakibatkan kompleks $\mathrm{Cu}$ (II)oksinat tidak stabil sehingga ion $\mathrm{Cu}$ (II) terperangkap di fasa sumber, sedangkan jika pH besar dari $3 \mathrm{Cu}$ (II) membentuk kompleks dengan ammonia yang dapat menghalangi terbentuknya kompleks $\mathrm{Cu}(\mathrm{oksin})_{2}$. Hal ini juga menyebabkan jumlah ion $\mathrm{Cu}(\mathrm{II})$ besar tersisa di fasa sumber.

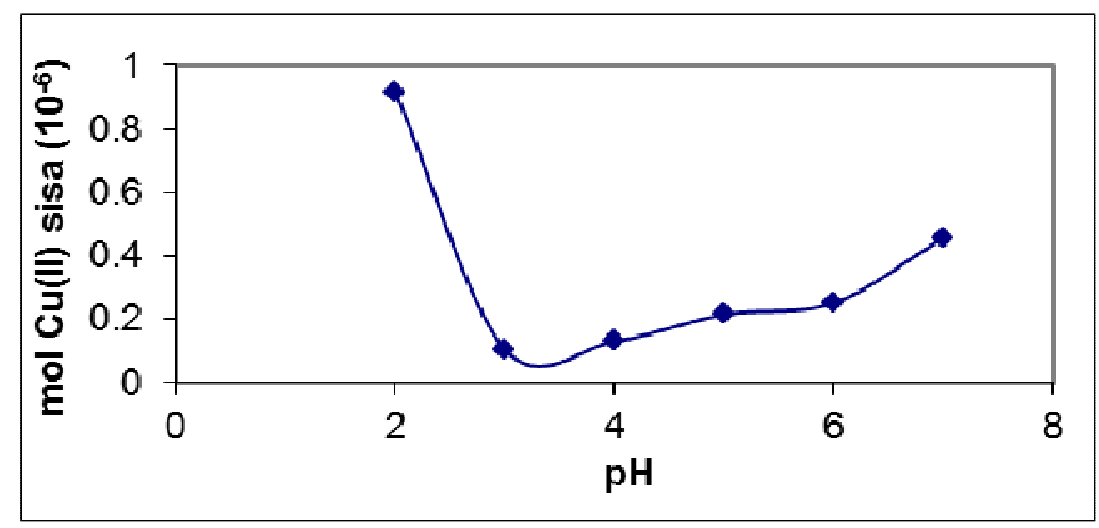

Gambar 2. Pengaruh $\mathrm{pH}$ fasa sumber terhadap jumlah ion $\mathrm{Cu}$ (II) yang tersisa di fasa sumber.

Kondisi Percobaan : fasa sumber di dalam ke-6 silinder masing-masing $5 \mathrm{~mL}$ ion $\mathrm{Cu}$ (II) 3,147 x

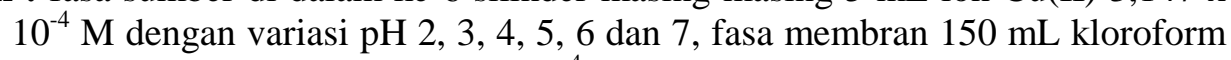
dengan konsentrasi oksin $17,5 \times 10^{-4} \mathrm{M}$, fasa penerima $35 \mathrm{~mL} \mathrm{H}_{2} \mathrm{SO}_{4} 0,15 \mathrm{M}$, waktu kesetimbangan 15 menit.

\section{Penentuan Konsentrasi Optimum Asam Sulfat Dalam Fasa Penerima}

Pada penelitian ini digunakan asam sulfat sebagai fasa penerima dan sumber ion hidrogen. Hal ini didasarkan pada penelitian sebelumnya didapatkan hasil bahwa asam sulfat adalah media penerima yang baik dibandingkan $\mathrm{HCl}, \mathrm{HNO}_{3}$, dan EDTA untuk transport ion $\mathrm{Cu}$ (II) melalui membran cair fasa ruah.
Berdasarkan penelitian yang dilakukan, didapatkan bahwa semakin tinggi konsentrasi asam sulfat yang digunakan maka semakin besar gradient konsentrasi ion hidrogen yang terjadi pada antarmuka fasa membran dengan fasa penerima. Hal ini proses dekompleksasi $\mathrm{Cu}(\text { oksin })_{2}$ akan mudah terjadi, maka ion $\mathrm{Cu}$ (II) tersebut akan cepat berdifusi ke dalam fasa penerima, mencapai optimum pada $\mathrm{H}_{2} \mathrm{SO}_{4}$ 0,15, ini ditunjukan oleh Gambar 3. 


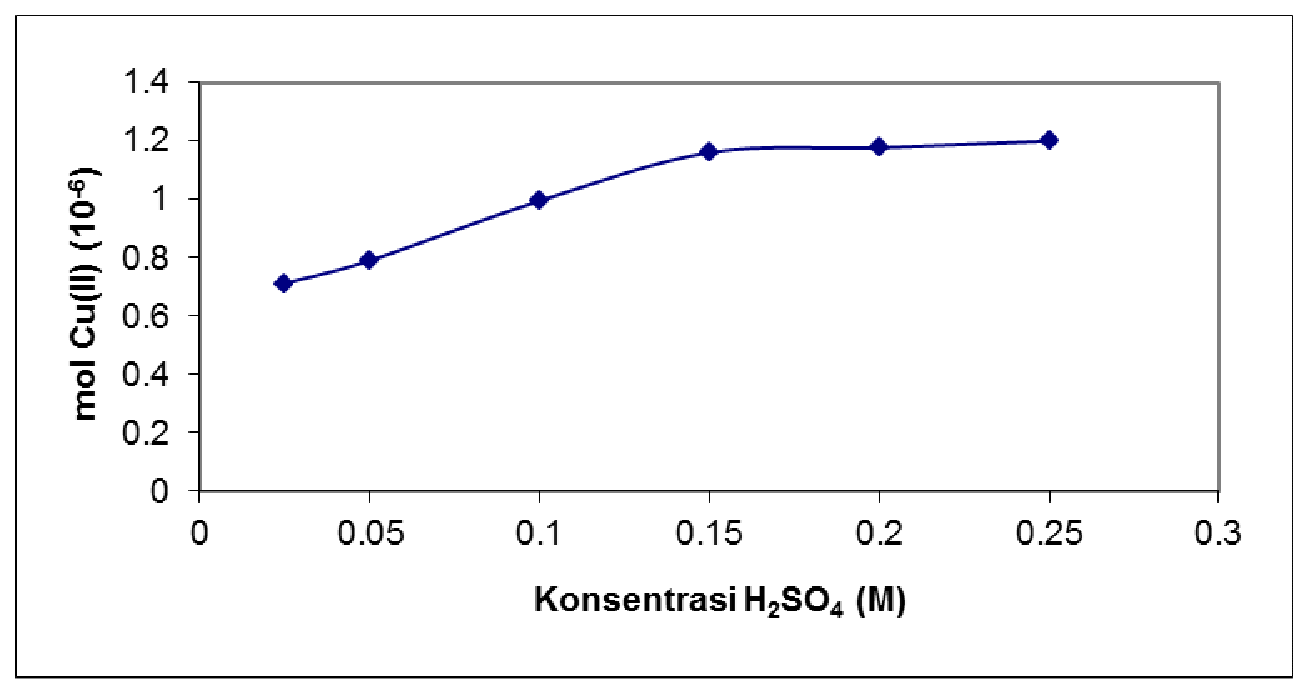

Gambar 3. Pengaruh konsentrasi asam sulfat terhadap mol $\mathrm{Cu}(\mathrm{II})$ dalam fasa penerima.

Kondisi Percobaan : fasa sumber $35 \mathrm{~mL}$ ion $\mathrm{Cu}(\mathrm{II}) 3,147$ x $10^{-4} \mathrm{M}$ pH 3, fasa membran $150 \mathrm{~mL}$ kloroform dengan konsentrasi oksin $17,5 \times 10^{-4} \mathrm{M}$, fasa penerima dalam ke-6 silinder masing-masing $5 \mathrm{~mL} \mathrm{H}_{2} \mathrm{SO}_{4}$ dengan konsentrasi 0,$025 ; 0,05 ; 0,1$; 0,15;0,2 dan 0,25 M, waktu kesetimbangan 15 menit.

\section{Penentuan Waktu Transpor Optimum}

Penentuan pengaruh waktu terhadap jumlah persentase transport ion $\mathrm{Cu}$ (II) melalui teknik membran cair fasa ruah secara simultan dilakukan dengan dua metoda percobaan berbeda yang dapat dilihat pada Gambar 4a dan 4b. Pada kondisi optimum transport yaitu fasa sumber ion $\mathrm{Cu}$ (II) $3,147 \times 10^{-4} \mathrm{M}$ dengan $\mathrm{pH} 3$ dan fasa penerima $\mathrm{H}_{2} \mathrm{SO}_{4} 0,15 \mathrm{M}$, terlihat bahwa persentase $\mathrm{Cu}$ (II) yang tersisa di fasa sumber menjadi semakin kecil dan yang tertranspor ke fasa penerima semakin meningkat mencapai optimum setelah 3 jam. Persentase ion $\mathrm{Cu}$ (II) sekitar $97,05 \%$ (metode simultan 1) dan 96,69\% (metode simultan 2).

Pada penelitian sebelumnya dengan menggunakan teknik membran cair fasa ruah metode safavi didapatkan waktu transport optimum ion $\mathrm{Cu}$ (II) adalah 6 jam dengan persen transport $97,3 \%$. Sehingga dapat diasumsikan bahwa sistem membran cair fasa ruah secara simultan dapat mempersingkat waktu transport ion $\mathrm{Cu}$ (II) dari fasa sumber ke fasa penerima. Hal ini disebabkan karena luas permukaan pada antarmuka fasa sumber dengan fasa membran serta fasa penerima yang semakin besar sehingga kecepatan transport antarfasa semakin meningkat.

\section{Kecepatan Proses Transpor Ion Cd(II) dari Fasa Sumber ke Fasa Penerima.}

Percobaan pengaruh variasi waktu transpor terhadap perubahan perbandingan konsetrasi ion $\mathrm{Cu}$ (II) sisa di fasa sumber dan yang tertranspor ke fasa penerima dapat memonitor setiap saat proses transpor ion $\mathrm{Cu}$ (II) melalui teknik membran cair fasa ruah secara simultan.

Berdasarkan Gambar 5a dan 5b, dapat dilihat bahwa perubahan konsentrasi ion $\mathrm{Cu}(\mathrm{II})$ dalam fasa sumber (Rs) menurun secara eksponensial terhadap variasi waktu transpor dan kemudian mencapai kesetimbangan dengan perubahan konsentrasi yang bertambah lambat dengan bertambahnya waktu.

Untuk perubahan konsentrasi ion $\mathrm{Cu}(\mathrm{II})$ dalam fasa penerima $(\mathrm{Rp})$ meningkat secara sigmoid terhadap waktu transpor. Dalam hal ini diasumsikan bahwa sistem transpor ion $\mathrm{Cu}$ (II) dari fasa sumber ke fasa penerima merupakan reaksi konsekutif irreversibel orde satu. Secara perhitungan untuk kedua metoda Rm mempunyai puncak maksimum pada menit ke- 
.20 walaupun tidak tampak terlalu jelas. Dimana $k_{l}$ adalah konstanta kecepatan tranpor ion $\mathrm{Cu}(\mathrm{II})$ masuk ke fasa membran dan $k_{2}$ adalah konstanta kecepatan tranpor ion $\mathrm{Cu}$ (II) keluar dari fasa membran. Nilai $k_{l}=$ $0,0442 /$ menit dan $k_{2}=0,0372 /$ menit telah dihitung dengan menggunakan persamaan (6), (7), dan (8) memenuhi reaksi orde satu. Dari data kedua metoda percobaan yang dilakukan, terlihat bahwa perhitungan nilai konstanta kecepatan transpor masuk ke membran $k_{l}$ adalah relatif lebih besar daripada nilai konstanta kecepatan transpor keluar dari membran $k_{2}$. Hasil yang diperoleh ini tidak jauh berbeda dengan metode membran cair fasa ruah yang tidak simultan yaitu $k_{1}=0$, $0,0454 /$ menit dan $k_{2}=0,0364 /$ menit $\left[{ }^{6}\right.$.
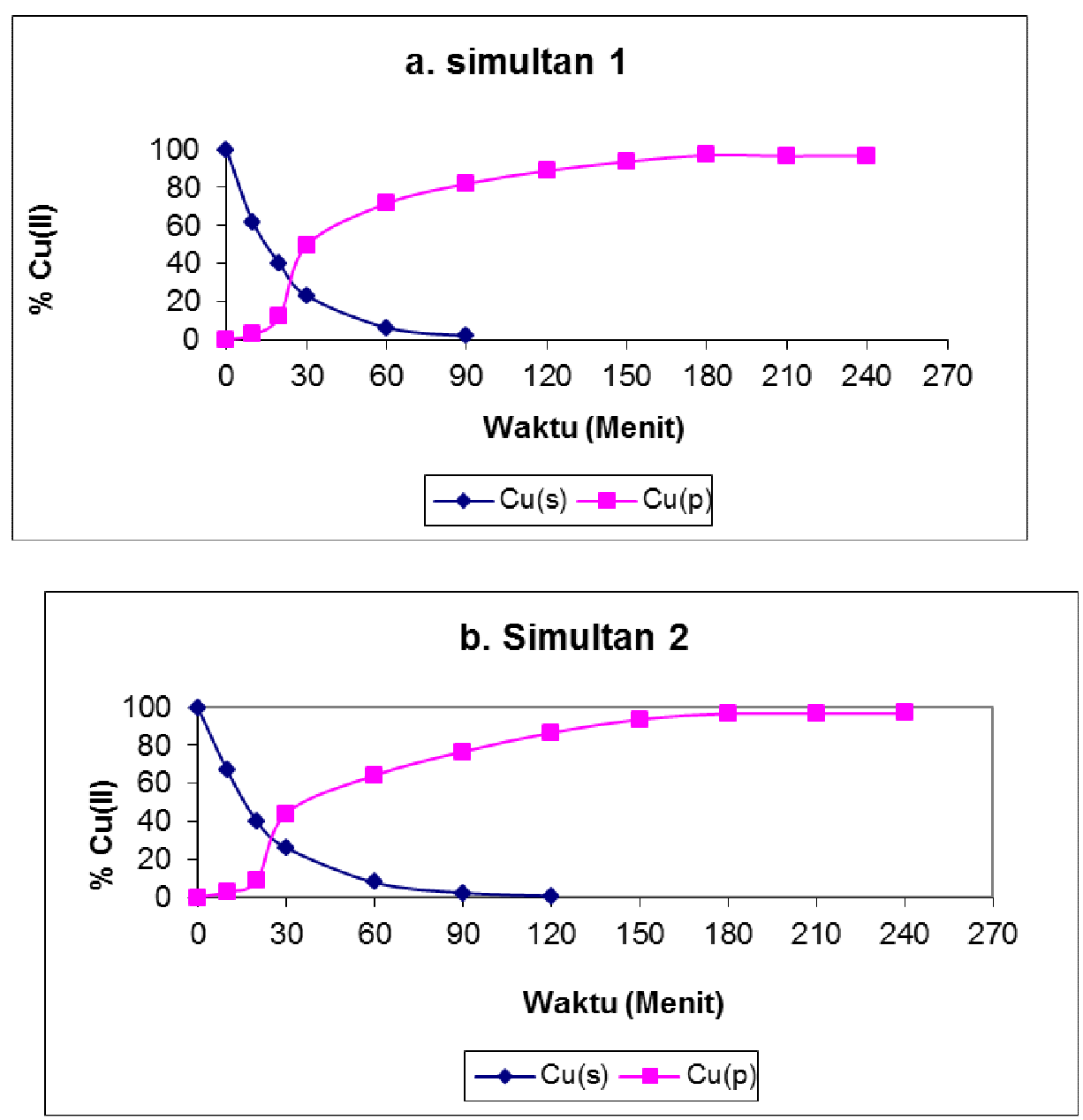

Gambar 4a dan 4b. Pengaruh waktu terhadap \% transpor ion $\mathrm{Cu}(\mathrm{II})$ ke fasa penerima ( ion $\mathrm{Cu}(\mathrm{II})$ sisa di fasa sumber $(\diamond)$ (metode simultan 1) dan ( metode simultan 2 ).

Kondisi Percobaan : Metode simultan 1.Fasa sumber dalam ke-6 silinder masing-masing $5 \mathrm{~mL}$ ion $\mathrm{Cu}$ (II) $3,147 \times 10^{-4} \mathrm{M}$ pH 3, fasa membran $150 \mathrm{~mL}$ kloroform dengan konsentrasi oksin $17,5 \times 10^{-4} \mathrm{M}$, fasa penerima $35 \mathrm{~mL} \mathrm{H}_{2} \mathrm{SO}_{4} 0,15 \mathrm{M}$..

Metode simultan 2.Fasa sumber $35 \mathrm{~mL}$ ion $\mathrm{Cu}$ (II) $3,147 \times 10^{-4} \mathrm{M}$ pH 3, fasa membran $150 \mathrm{~mL}$ kloroform dengan konsentrasi oksin $17,5 \times 10^{-4} \mathrm{M}$, fasa penerima dalam ke 6 silinder masing-masing $5 \mathrm{~mL} \mathrm{H}_{2} \mathrm{SO}_{4} 0,15 \mathrm{M}$. 

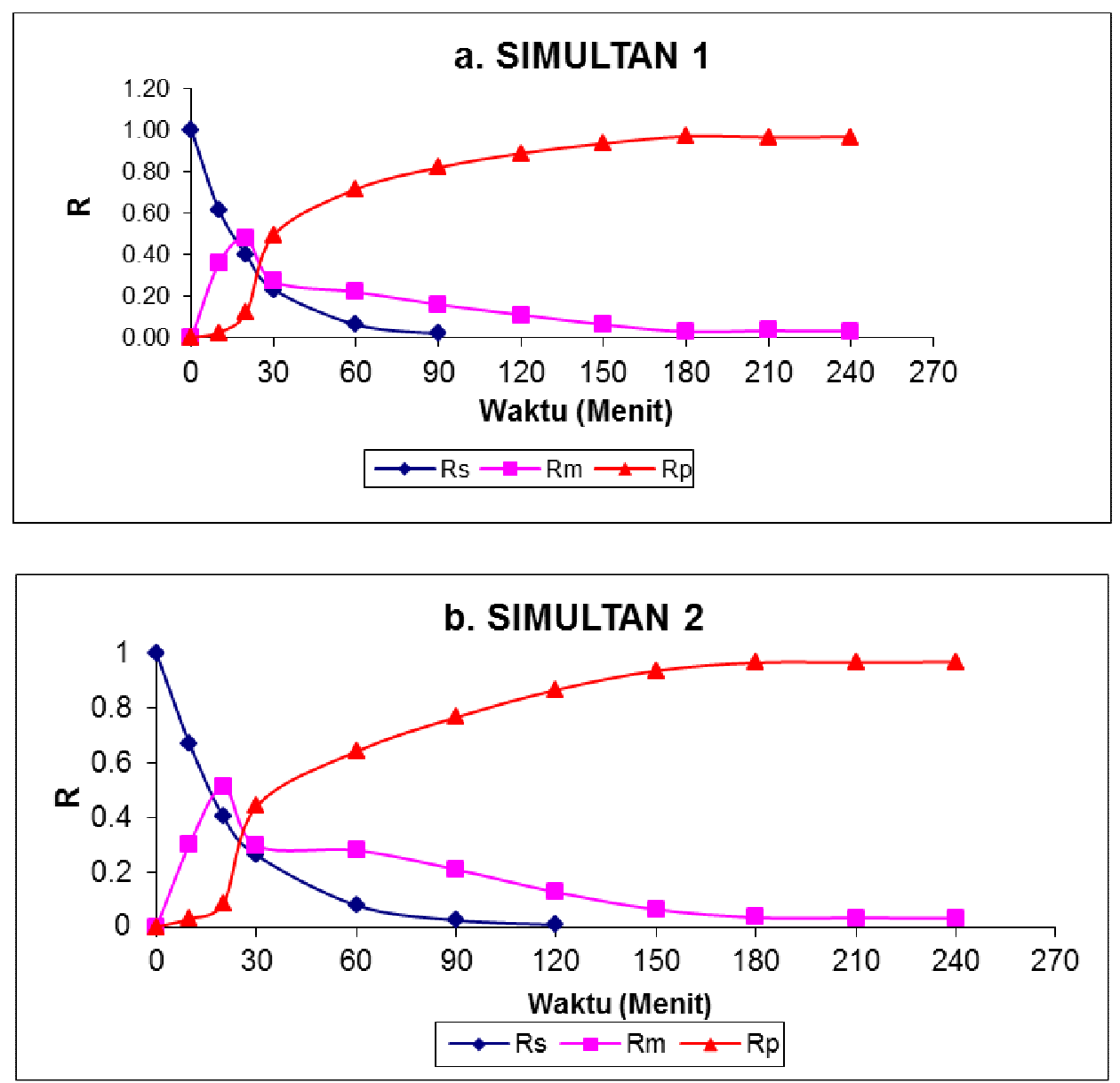

Gambar 5a dan 5b.Perubahan perbandingan konsentrasi ion $\mathrm{Cu}$ (II) dalam fasa sumber (Rs), fasa membran (Rm), dan fasa penerima (Rp) terhadap waktu (metode simultan 1) dan ( metode simultan 2)

Kondisi Percobaan : Metode simultan 1 : fasa sumber dalam ke-6 silinder masing-masing $5 \mathrm{~mL}$ ion $\mathrm{Cu}$ (II) $3,147 \times 10^{-4} \mathrm{M}$ pH 3, fasa membran $150 \mathrm{~mL}$ kloroform dengan konsentrasi oksin $17,5 \times 10^{-4} \mathrm{M}$, fasa penerima $35 \mathrm{~mL} \mathrm{H}_{2} \mathrm{SO}_{4} 0,15$ $\mathrm{M}$, waktu kesetimbangan 5 menit.

Metode simultan 2: fasa sumber $35 \mathrm{~mL}$ ion $\mathrm{Cu}(\mathrm{II}) 3,147 \times 10^{-4} \mathrm{M} \mathrm{pH}$ 3, fasa membran $150 \mathrm{~mL}$ kloroform dengan konsentrasi oksin $17,5 \times 10^{-4} \mathrm{M}$, fasa penerima dalam ke-6 silinder masing-masing $5 \mathrm{~mL} \mathrm{H}_{2} \mathrm{SO}_{4} 0,15 \mathrm{M}$, waktu kesetimbangan 5 menit.

\section{KESIMPULAN}

Dari hasil penelitian dapat disimpulkan bahwa transport ion $\mathrm{Cu}$ (II) melalui teknik membran cair fasa ruah secara simultan dengan oksin sebagai pembawa mempunyai kondisi optimum sebagai berikut : $\mathrm{pH}$ fasa sumber adalah 3 dan fasa penerima adalah asam sulfat dengan konsentrasi 0,15 M. Kinetika proses transport pada metode simultan memenuhi hukum kinetika reaksi konsekutif irreversibdel orde satu. Nilai konstanta kecepatan transport masuk membran $k_{1} \quad 0,0442$ menit $^{-1}$ dan konstanta ke luar membran $k_{2}$ 0,0372 menit $^{-}$ ${ }^{1}$.Nilai tersebut tidak jauh berbeda dengan nilai yang didapat pada penelitian sebelumnya. Metoda membran cair fasa ruah secara simultan dapat dijadikan alternatif dalam penentuan kondisi optimum transport ion logam dan kinetika transport ion tersebut. 


\section{DAFTAR PUSTAKA}

1. Parham, H., and Shamsipur, M. Selective Membrane Transport of $\mathrm{Pb}^{2+}$ Ion By A Cooperative Carrier composed of 18Crown-6, Tetrabutylammonium Iodide and Palmitic Acid.J.Membr.Sci.95: 21-27 (1994).

2. Mulder, M. Basic Principle of Membrane Technology. Kluwer Academic Publisher, Dordrencht. Pp.244-259.( 1991) .

3. Coelhoso, I.M, Crespo, J.P.S.G, Carrondo, M.J.T, Kinetics of Liquid Membrane Extraction in System With Variable Distribution Coefficient. J.Memb.Sci. 127 : 141-152 (1997).

4. Refinel “, Penentuan Kondisi Optimum Transpor Ion $\mathrm{Cd}(\mathrm{II})$ melalui Teknik Membran Cair Fasa Ruah secara Simultan dengan Oksin sebagai pembawa ", Proseding Semirata, FMIPA - Unri Pekanbaru, (2010).

5. Olly N.T. Interphase Molecular Transport of $\mathrm{Cu}$ (II) Through Bulk Liquid Membrane by Using Oxine As Zat pembawa. Poster In Internasional Meeting on $21^{\text {st }}$ Century From Modern Chemistry To Industries And Environment, (2000).

6. Refinel, Zaharasmi dan Olly, "Kinetika Transpor $\mathrm{Cu}(\mathrm{II})$ oleh zat pembawa Oksin dengan dan tanpa asam Oleat melalui membran cair fasa ruah", Jurnal Riset Kimia (2),2, hal 127-131, (2009). 